\title{
E-learning in Organizations: Factors Affecting Individual Job Performances
}

\author{
https://doi.org/10.3991/ijet.v17i02.26967 \\ Belma Čevra, Amra Kapo ${ }^{(凶)}$, Tarik Zaimović, Lejla Turulja \\ School of Economics and Business, University of Sarajevo, Sarajevo, Bosnia and Herzegovina \\ amra.kapo@efsa.unsa.ba
}

\begin{abstract}
As we look at our daily lives and the world around us, it is becoming more and more difficult to learn new things and our new knowledge is suffering because of the fast and intense way of life we lead. The development of technology has greatly influenced this way of life. In recent years, we have witnessed the rapid growth and development of technology and seen how technology affects many aspects of our lives. Therefore, the aim of this paper is to contribute to the understanding of the concept of e-learning in organizations and the influence of organizational support on the intention to use e-learning systems and how the use of e-learning improves individual work performance. The paper used structural equation modeling technique to test the hypotheses at the level of employees in different sectors. The results showed that the most significant predictor of individual job performance was intention to use e-learning, followed by knowledge sharing. In addition, the results showed that knowledge sharing and personal innovativeness were significant predictors of perceived usefulness.
\end{abstract}

Keywords—education at work, lifelong learning, adult learning, 21st-century abilities, individual job performances, organizational support

\section{Introduction}

We live in a world of rapid technological advancement where it has become imperative to be "online", both personally and professionally. Today's workforce is expected to be highly skilled, constantly improving their skills and acquiring new skills through lifelong learning[1], [2]. Insufficient time and the fast pace of life require employees to adapt in all areas, including learning. The increasing number of COVID -19 cases requires distance learning and promotes its rapid growth. E-learning, defined as online learning and teaching using network technologies, is undoubtedly one of the most powerful responses to the growing need for education [3]. The goal of elearning is to build knowledge that is transferable to the workplace and skills that are directly related to organizational performance, or to help individuals achieve personal learning goals [4]. Workplace learning can be summarized in the tools, processes, and activities in the workplace through which employees learn from basic skills to hightech and managerial practices that are directly applied to their jobs, tasks, and roles. It 
includes both formal and non-formal learning. From a consumer behavior perspective, people who are willing to use e-learning are no different from customers in e-learning environments, given their requirements for both learning quality and personal satisfaction [5]. It is obvious that we live in a time of great and constant changes, where organizations have to adapt very quickly to all changes if they want to maintain their competitiveness and have a good position in the market competition. As a result, many organizations have replaced the traditional way of training employees with elearning systems. However, for e-learning to work successfully, it is not enough to just implement the system. Understanding the factors that influence users' intention to use e-learning not only helps e-learning system developers to design popular content, but also helps teachers and providers to develop strategies that tend to increase the use of e-learning systems [6]. If we talk about the factors that influence the use of an elearning system, then it is certainly necessary to emphasize the importance of organizational support. [7] Argue that employees who perceive greater organizational support find their work more enjoyable, perform their tasks in a better mood, and suffer from fewer stress symptoms such as anxiety. If the information system is supported by different levels of management, users and designers will feel positive. In addition to organizational support, an important fact is the personal characteristic of the user, i.e., personal innovativeness. Moreover, it has been found in the scientific literature that knowledge sharing is an important predictor of intention to use a particular technology [8]-[11]. Collecting knowledge is easy, but sharing it is more difficult. More and more companies are beginning to realize that shared knowledge is knowledge skillfully used and utilized [12]. This is why many researchers place emphasis on incentive systems for successful knowledge management. For this reason, many researchers focus on incentive systems for successful knowledge management. Finally, another important effect of e-learning use is higher individual job performance, which is associated with e-learning use in academic discourse. Although some knowledge can be acquired through e-learning systems, it is still controversial whether this outcome can improve job performance[13].

This is divided into five sections as follows. First, the theoretical basis of this study is pointed out and an overview of previous studies in this field is given. Then, relevant hypotheses are derived to develop structural models with relationships based on organizational support theory. This is followed by the methodology, data analysis and the results section where we test our model. Finally, we summarize the conclusions and discuss the results with the presentation of limitations and future research directions in this area.

\section{Development of conceptual model and hypotheses}

As mentioned earlier, e-learning is an interesting topic that is constantly evolving and has a lot of room for research. The factor that raises the most questions and doubts in this whole scientific field and is considered crucial when it comes to elearning is the intention to use the e-learning system once it is implemented. While the flexibility and abundance of learning resources are the main advantages of e- 
learning systems, they are also challenging for users who are not accustomed to the elearning environment[14]. Many users drop out of their online courses prematurely, resulting in a high retention rate for e-learning compared to traditional face-to-face instruction under the guidance of a lecturer[15]. Certainly, there are many factors that influence the intention to use or retain the use of e-learning systems, and one of the most important ones that we will focus on in this paper is organizational support. When employees feel that the organization is making significant efforts to implement new technologies, a climate is created that influences employee behavior by changing their attitudes and perceptions within the organization [16]. Employee involvement in e-learning is a change that should be managed at all levels of the organization. Primarily, this change should be reflected in the strategic documents of the organization. In integrating the e-learning system, companies should also provide incentives that motivate employees to participate [17]. Studies suggest that organizational policies and procedures are a critical dimension of a work environment conducive to learning. Therefore, the elements that make up the organizational policy infrastructure, such as business strategies, incentive systems, financial and budgetary support for staff development, and organizational decision-making structure, are critical factors for the success of e-learning [18]. The purpose of this research is to determine the influence of organizational support on the intention to use the e-learning system. Therefore, the following hypothesis is proposed:

H1: Organizational support has a positive impact on the intention to use the elearning system.

Organizational support when using an e-learning system will lead to better work performance of an individual. [19] stated that perceived organizational support and an individual's work performance are positively related and also confirmed by [20], [21]. Even when employee performance is unsatisfactory, a firm can improve the situation by focusing on employee needs and concerns. Once employees feel organizational support, they are motivated to reciprocate with quality results [22], [23]. [24] Consider perceived organizational support from a resource allocation perspective and suggest that perceived organizational support provides resources that enable workers to achieve work goals. These resources come not only in the form of socio-emotional support, but also in the form of equipment, physical assistance, funding, technology and ideas [25]. As we can see, in the professional literature, emphasis is often placed on the correlation between organizational support and the work performance of an individual, and in this part of the research, an analysis of the mentioned correlation will be performed. Therefore, we propose following hypothesis:

$\mathrm{H}$ 2: Organizational support has a positive impact on individual job performance.

E-learning has become the leading way to disseminate knowledge in the business environment, whether it is large, medium, or small organizations and companies. The main goal of any company or organization is to improve business results. One of the ways to achieve the above goal is certainly to incorporate online training, education or simply "embedding" the concept of lifelong education and learning of any form in the pores of the company. Technology is known to fit well into any private, school, or work assignment, and to improve employee performance [26]. Precisely because of the above, we will link the intention to use in individual job performance since the 
intention to use in technology is a predictor of use and continuous use, and reflects the willingness of people to use technology and be dependent on them [27], [28]. In accordance with this research, the following hypothesis was defined:

$\mathrm{H} 3$ : Intention to use has a positive impact on individual job performance.

Along with the very thought of e-learning as a new and modern way of learning, we naturally associate the concept of innovation. It is inevitable that the factor of personal innovation in this whole story stands out as one of the important factors. While several variables of individual differences could potentially affect how individuals respond to innovation, personal innovativeness, as a construct important for studying an individual's behavior toward innovation, has a long tradition of researching the diffusion of innovation in general [29]. Therefore, the question arises as to how this personal innovativeness as a direct or indirect factor affects the intention to use the e-learning system? What is the advantage of people who are naturally inclined to adopt the new and unknown in relation to those who are not? Individuals who have a high level of innovation positively recognize the relative benefits and ease of use; accordingly, they demonstrate a greater intention to use new information technology [30]. [31] Concluded that personal innovativeness determines the user's perception of usefulness and the perception of ease of use in the short and long term, and ultimately influences the attitude towards the acceptance and intention to use new technology. In accordance with the given research, the paper will analyze the impact of personal innovativeness on the perceived usefulness of e-learning systems, and propose the following hypothesis:

H4: Personal innovativeness has a positive impact on the perceived usefulness of elearning systems.

If we lay down and in the simplest way try to define the purpose of the e-learning system, the answer would most likely be the acquisition and exchange of knowledge. In addition to the acquisition of knowledge, which is clearly the primary goal of using e-learning systems, the exchange of knowledge is one of the factors that has proven to be extremely important among users of e-learning systems. Knowledge sharing is defined as providing task information and knowledge on how to help others and collaborate with others to solve problems, develop new ideas or implement policies and procedures [32]. Some of the important elements discussed in the literature dealing with knowledge sharing are trust, shared vision, and connections between social interactions. These elements were considered important elements in encouraging the exchange of knowledge, which were needed during the implementation of the knowledge management system [33]. [34] Note that the expected association and contribution are the main factors of an individual's attitude towards knowledge exchange. In this case, "expected association" means that employees believe they could improve their relationship with other employees by offering them their knowledge, and "expected contribution" means that employees believe they could contribute to the success of the organization. [35]. In their research, [35] analyzed the relationship between technology acceptance and participation in knowledge sharing; they found significant correlations between knowledge sharing and technology acceptance. As mentioned earlier, evidence from the literature indicates a positive relationship between knowledge sharing and perceived usefulness and perceived ease of use of a 
particular technology [36], [37]. Empirical results have shown that knowledge acquisition, knowledge exchange, perceived usefulness and perceived ease of use have a positive direct impact on the intention to use e-learning systems [38]. [37] In his research proves that knowledge sharing is the most significant factor influencing the perceived usefulness of technology as well as individual job performance. Therefore, according to the above data, we propose the following hypotheses:

H5: Knowledge sharing has positive impact on individual job performance.

H6: Knowledge sharing has a positive impact on the perceived usefulness of elearning systems.

The TAM (Technology Acceptance Model), created by [39] proposes that perceived ease of use and perceived usefulness of technology are predictors of user attitudes toward technology use, subsequent behavioral intentions, and actual use. Including results from many years of information systems research, TAM may be particularly suitable for modeling computer acceptance, including Internet services [40]. If we look at this problem from the side, not considering what the results of numerous studies require, looking logically from the perspective of any person who has been in contact with new technology throughout life, then each user can conclude that if we perceive that certain technology is useful for various reasons, it will result in an increase of intention and willingness to use the same. In addition, the impact of perceived usefulness on the intention to use an e-learning system has certainly been analyzed through many studies and is very often mentioned in the literature dealing with e-learning such as [41]. Previous studies examining the use of IS have found that the perceived usefulness of IS is a critical perception that triggers the intention to continue using the information system [42], [43]. [44] Suggest the usefulness of IS as a central success factor in a modified version of the IS success model. The intention to continue using IS is a critical issue addressed by research, but it is also important to understand the behavior after IS adoption and the factors that drive it. Studies show that the perceived usefulness of IS, which has been found to influence the initial adoption of IS, also plays an important role in the use of IS after adoption [45]. Analyzing the existing literature, we can clearly see the importance of research and analysis of the impact of perceived usefulness on the intention to use e-learning systems, and accordingly we propose the following hypothesis:

H7: The perceived usefulness of the e-learning system has a positive impact on the intention to use the e-learning system.

In accordance with the stated and explained research hypotheses, the conceptual research model is presented in Figure 1: 


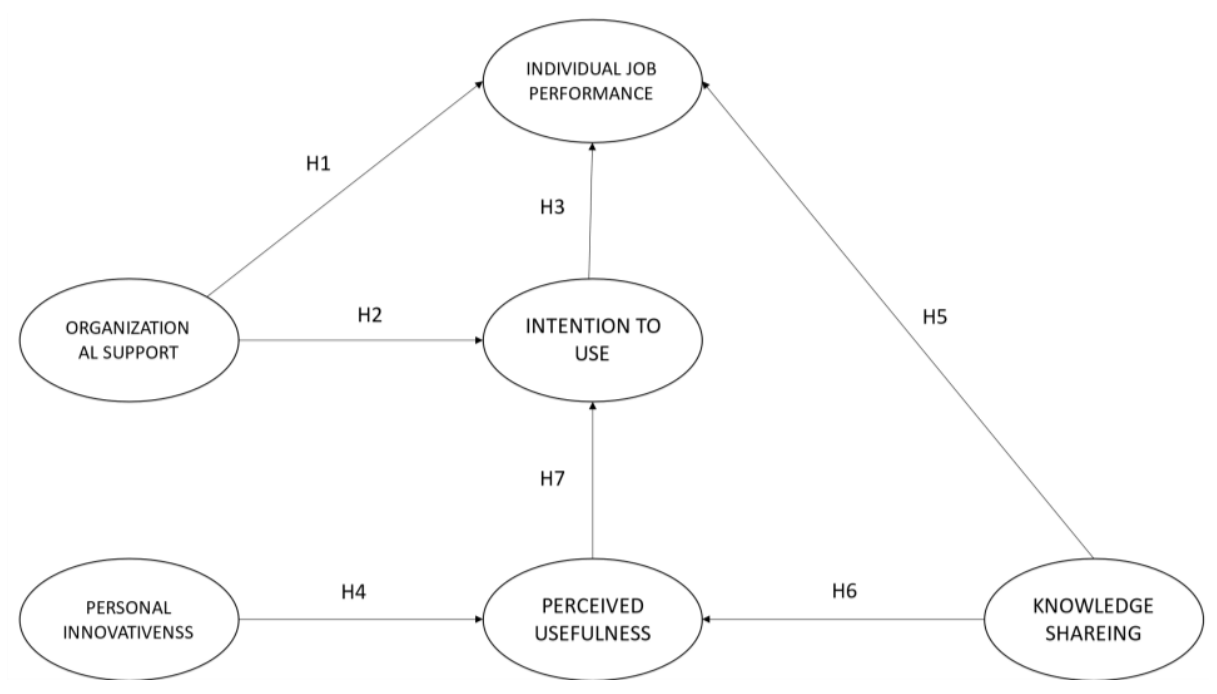

Fig. 1. Conceptual model

\section{$3 \quad$ Methodology}

\subsection{Sample characteristics}

The snowball method [46], [47] was used in this study, which is a method of nonrandom sampling where the starting point is the initial identification of a certain number of members of the target population who meet the criteria to enter the sample. They represent the initial source of the requested information and through them other members are reached who refer to other persons who meet the set criteria. This process continues until the desired sample size is reached. In the case of this paper, the questionnaire was distributed by e-mail to companies, i.e., individuals who meet the above criteria in order for employees of these companies to complete the questionnaire. The questionnaire was created using the software tool LimeSurvey. The number of finalized questionnaires was 240. During initial check of collected data, 18 outliers were detected and removed from the sample and 222 observations remained for analysis, which was a relevant sample for this study.

In addition to the 6 groups that contained questions on organizational support, perceived usefulness of the e-learning system, personal innovativeness, knowledge exchange, intent to use and work performance, the questionnaire also contained questions related to the demographic characteristics of respondents. These were questions about gender, age, level of education, position in the company, and ownership of the company. In Table 1 we can see detailed information about the respondents. 
Table 1. Demographic characteristics of respondents

\begin{tabular}{|l|c|c|}
\hline \multicolumn{1}{|c|}{ Characteristics } & n & \% \\
\hline Gender & 98 & $44 \%$ \\
\hline Female & 124 & $56 \%$ \\
\hline Male & \multicolumn{2}{|l|}{} \\
\hline Age & 30 & $13 \%$ \\
\hline $18-25$ & 58 & $26 \%$ \\
\hline $26-35$ & 57 & $26 \%$ \\
\hline $36-45$ & 58 & $26 \%$ \\
\hline $46-55$ & 19 & $9 \%$ \\
\hline $56-65$ & \multicolumn{2}{|l|}{} \\
\hline Level of education & 0 & $0 \%$ \\
\hline Elementary education & 25 & $11 \%$ \\
\hline Secondary education & 10 & $5 \%$ \\
\hline College education & 123 & $55 \%$ \\
\hline Higher education & 56 & $25 \%$ \\
\hline Master or similar & 8 & $4 \%$ \\
\hline PhD & \multicolumn{2}{|l|}{} \\
\hline
\end{tabular}

Through the analysis of descriptive statistics of the sample we can see that 98 women participated in the research, which is $44 \%$ and 124 males, which is $56 \%$. Therefore, we conclude that men were slightly more represented in the study. When we talk about the age of the respondents, the same percentage of $26 \%$ had three age groups: from 26 to 35 (58 respondents), from 36 to 45 (57 respondents) and from 46 to 55 (58 respondents). Furthermore, 30 respondents belonged to the age group from 18 to 25 , which is a percentage of $13 \%$ and 19 respondents, ie $9 \%$ were from the age group from 56 to 65 years. What was also examined as an important item is the level of education of the respondents, where the largest number of respondents, more precisely 123 , had a university degree, which is a percentage of $55 \%$. This is followed by 56 subjects who are MA or MR, which is $25 \%, 25$ subjects, ie $11 \%$ with a high school diploma, and 10 subjects, i.e. 5\% with a university degree. 8 respondents declared themselves as DR, which represents a percentage of $4 \%$, while there are no respondents who have only primary education.

\subsection{Measures}

When it comes to measuring scales, indicators are largely adopted from previous literature. We used a total of 20 indicators for the proposed research model. These indicators attempted to quantify organizational support, perceived usefulness, individual job performances, personal innovativeness, knowledge sharing and intention to use. items were measured using a seven-point Likert scale with anchors from $1=$ "strongly disagree" to 7 = "strongly agree". The indicators, originally in the English language, were translated into the local language. Two academic experts were engaged in the process of the questionnaire adaptation. 
The organizational support construct containing four indicators was adopted from [48]. The construct of perceived usefulness refers to how the use of e-learning system will be useful in acquiring new knowledge, organization, and more effective learning, improving learning in the workplace, faster acquisition of new knowledge and skills related to work, and the usefulness of e-learning system in forming positive work atmosphere among colleagues and establishing the practice of knowledge exchange. All items are adopted from [49]. The construct of personal innovativeness was measured by three statements. They refer to the tendency to experiment with new technologies, hesitation in adopting new technologies, and self-initiative in discovering and adopting new technologies. All items are adopted from [30]. The knowledge sharing construct was measured with three items. They relate to all the potential benefits that knowledge sharing through e-learning systems brings, such as: flexibility in place and time, support for discussion, strengthening relationships with the instructor and colleagues, and facilitating collaboration. Measures are adapted from [38]. The construct of intent to use the e-learning system was measured through three items. They relate to whether the user, if he has access to the e-learning system, intends to use it, and, if he intends to continue using it, in what way and for what e-learning will be used, as well as whether the user intends to use e-learning instead of the traditional way of learning. The items are adapted from [42], [50], [51]. The construct of an individual's work performance was measured through four items and they are adopted from [52] and relate generally to the attitudes of employees regarding their performance in the organization.

Prior to the implementation of the research process, the content validity of the questionnaire was checked by experts from the academic and business community. Content validity implies understanding the meaning and content of each variable. The content validity of the questionnaire was checked by three experts from the business community and one expert from the academic community. The online version of the questionnaire was sent to them by e-mail and they fill out the questionnaire and leave their comments on it. Based on the comments received from these persons, the necessary corrections were made.

Table 2. Measures

\begin{tabular}{|c|c|c|}
\hline Construct & Item & Source \\
\hline \multirow[t]{3}{*}{$\begin{array}{l}\text { Organizational } \\
\text { support }\end{array}$} & $\begin{array}{l}\text { The company I work for has a performance appraisal system that links financial } \\
\text { rewards to the use of newly acquired knowledge and skills. }\end{array}$ & [53] \\
\hline & $\begin{array}{l}\text { In the company where I work, there are rewards and incentives for acquiring and } \\
\text { using new knowledge and skills in business. }\end{array}$ & \\
\hline & $\begin{array}{l}\text { The company I work for rewards employees for using newly acquired } \\
\text { knowledge and skills at work. }\end{array}$ & \\
\hline \multirow[t]{4}{*}{$\begin{array}{l}\text { Perceived } \\
\text { usefulness }\end{array}$} & $\begin{array}{l}\text { An e-learning system would be useful for me to construct knowledge in my } \\
\text { work context. }\end{array}$ & [49] \\
\hline & $\begin{array}{l}\text { Using an e-learning system would allow me to organize my learning more } \\
\text { efficiently. }\end{array}$ & \\
\hline & $\begin{array}{l}\text { Using an e-learning system would increase the efficiency of my job-related } \\
\text { learning. }\end{array}$ & \\
\hline & Using an e-learning system at my job would allow me to acquire job-related & \\
\hline
\end{tabular}


Paper-E-learning in Organizations: Factors Affecting Individual Job Performances

\begin{tabular}{|c|c|c|}
\hline & competencies faster. & \\
\hline \multirow[t]{3}{*}{$\begin{array}{l}\text { Personal inno- } \\
\text { vativeness }\end{array}$} & $\begin{array}{l}\text { If I heard about new information technology, I would look for ways to experi- } \\
\text { ment with it. }\end{array}$ & [30] \\
\hline & Among peers and colleagues, I am usually the first to try new information. & \\
\hline & I like to experiment with new information technologies. & \\
\hline \multirow[t]{3}{*}{$\begin{array}{l}\text { Knowledge } \\
\text { sharing }\end{array}$} & $\begin{array}{l}\text { The e-learning system supports conversations with my lecturer and work col- } \\
\text { leagues. }\end{array}$ & [38] \\
\hline & $\begin{array}{l}\text { The e-learning system allows me to share different types of resources with my } \\
\text { lecturer and work colleagues. }\end{array}$ & \\
\hline & The e-learning system facilitates collaboration among work colleagues. & \\
\hline \multirow[t]{3}{*}{ Intention to use } & I intend to continue using the e-learning system to gather knowledge. & [42] \\
\hline & I intend to continue using the e-learning system to build knowledge. & \\
\hline & I intend to continue using e-learning to share knowledge. & \\
\hline \multirow[t]{4}{*}{$\begin{array}{l}\text { Individual job } \\
\text { performance }\end{array}$} & Using an e-learning system improves productivity in doing my job. & [52] \\
\hline & $\begin{array}{l}\text { Using an e-learning system improves my efficiency / effectiveness in doing my } \\
\text { job. }\end{array}$ & \\
\hline & All in all, e-learning is useful in doing my job. & \\
\hline & I am satisfied with the effects of using e-learning on my job. & \\
\hline
\end{tabular}

\section{Data analysis}

\subsection{Measurement model}

Validity and reliability. Data analysis was conducted following two-step procedure recommended by [54]. The first step involved the validity of measurement models by examining their reliability, convergent, and discriminatory validity.

Content validity was confirmed with the process of adopting items from the existing literature considering the construct definitions. Convergent validity was confirmed by checking the value of the standardized factor loadings. The coefficient of internal consistency is a popular coefficient of reliability testing [55], [56] whose value, according to [57] should not be less than $0.5(\alpha>0.5)$. In our case, factor loading coefficients ranging from 0.785 to 0.919 , indicating the internal consistency and reliability of the measures as they exceed the 0.50 cut-off limit, which is presented in Table 3.

Table 3 shows the final results after confirmatory factor analysis. After checking the suitability of the model and respecification, model was created for which both reliability and validity were checked. Model reliability is a data testing technique that aims to confirm theoretical assumptions. Reliability is measured through the use of a composite reliability (CR) measure, whose value should not be less than 0.6 , while values above 0.7 adequately measure reliability [57]. In Table 3 we can see that for all measurement models $\mathrm{CR}$ is greater than 0.7 , which confirms the reliability of the measurement model. When it comes to the validity of measurement models, convergent and discriminant validity was checked. In convergent validity, the relationship between a latent construct and the manifest variables that bind to that construct is 
tested. We checked it using the values of the average derived variance (AVE) and factor loads, as the most common measures of convergent validity. A value of standardized factor loads greater than 0.50 [57] and an AVE greater than 0.5 represent appropriate convergence. Therefore, in Table 3 we can see that all values of the average derived variance (AVE) are greater than 0.5 and that the value of all standardized factor loadings are greater than 0.50. Satisfaction of these criteria confirms the convergent validity of the measurement model.

Table 3. Loadings, reliability and validity

\begin{tabular}{|c|c|c|c|c|}
\hline Item & St. Loadings & Cronbach's Alpha & CR & AVE \\
\hline li1_1 & 0.816 & 0.822 & 0.894 & 0.738 \\
\hline li2_1 & 0.875 & & & \\
\hline li3_1 & 0.884 & & & \\
\hline nk2_1 & 0.928 & 0.906 & 0.941 & 0.842 \\
\hline nk2_2 & 0.926 & & & \\
\hline nk2_3 & 0.898 & & & \\
\hline op1_1 & 0.877 & 0.816 & 0.891 & 0.732 \\
\hline op2_1 & 0.901 & & & \\
\hline op2_2 & 0.785 & & & \\
\hline pk2_1 & 0.863 & 0.922 & 0.945 & 0.811 \\
\hline pk2_2 & 0.919 & & & \\
\hline pk2_3 & 0.913 & & & \\
\hline pk2_4 & 0.905 & & & \\
\hline ru6_1 & 0.857 & 0.881 & 0.918 & 0.736 \\
\hline ru6_2 & 0.864 & & & \\
\hline ru7_1 & 0.870 & & & \\
\hline ru7_2 & 0.840 & & & \\
\hline rz1_2 & 0.901 & 0.856 & 0.912 & 0.777 \\
\hline rz1_3 & 0.882 & & & \\
\hline rz1_4 & 0.860 & & & \\
\hline
\end{tabular}

Discriminant validity is a measure that tests the diversity of constructs within a model. The verification method used in this paper is to compare the square root of the AVE value with the correlation values of that construct with other constructs. According to [58] the square root of the average derived variance must be greater than the correlations between the constructs. Table 4 presents the correlation matrix below the diagonal, while the values of the square root AVE are presented on the diagonal. As can be concluded from the above, all constructs meet the condition of discriminatory validity. 
Table 4. Correlation matrix for discriminant validity

\begin{tabular}{|l|c|c|c|c|c|c|}
\hline \multicolumn{1}{|c|}{ Construct } & $\begin{array}{c}\text { Individual } \\
\text { job per- } \\
\text { formance }\end{array}$ & $\begin{array}{c}\text { Intention } \\
\text { to use }\end{array}$ & $\begin{array}{c}\text { Knowledge } \\
\text { sharing }\end{array}$ & $\begin{array}{c}\text { Organiza- } \\
\text { tional } \\
\text { support }\end{array}$ & $\begin{array}{c}\text { Perceived } \\
\text { usefulness }\end{array}$ & $\begin{array}{c}\text { Personal } \\
\text { innovative- } \\
\text { ness }\end{array}$ \\
\hline Individual job performance & $\mathbf{0 . 8 5 8}$ & & & & & \\
\hline Intention to use & 0.593 & $\mathbf{0 . 9 1 8}$ & & & & \\
\hline Knowledge sharing & 0.514 & 0.381 & $\mathbf{0 . 8 8 1}$ & & & \\
\hline Organizational support & 0.390 & 0.216 & 0.299 & $\mathbf{0 . 8 5 6}$ & & \\
\hline Perceived usefulness & 0.448 & 0.429 & 0.455 & 0.306 & $\mathbf{0 . 9 0 0}$ & \\
\hline Personal innovativeness & 0.383 & 0.499 & 0.275 & 0.246 & 0.433 & $\mathbf{0 . 8 5 9}$ \\
\hline
\end{tabular}

Note: Bold values represent Square-root of AVE

Discriminant validity was also assessed using hetrotrait-monotrait ratio (HTMT ratio) correlations. According to [59] all values need to be below 0.9 acceptable threshold. This also confirms that we do not have problems with discriminant validity (Table 5).

Table 5. HTMT ratio

\begin{tabular}{|l|c|c|c|c|c|c|}
\hline \multicolumn{1}{|c|}{ Construct } & $\begin{array}{c}\text { Individual } \\
\text { job perfor- } \\
\text { mance }\end{array}$ & $\begin{array}{c}\text { Intention } \\
\text { to use }\end{array}$ & $\begin{array}{c}\text { Knowledge } \\
\text { sharing }\end{array}$ & $\begin{array}{c}\text { Organizational } \\
\text { support }\end{array}$ & $\begin{array}{c}\text { Perceived } \\
\text { usefulness }\end{array}$ & $\begin{array}{c}\text { Personal } \\
\text { innovative- } \\
\text { ness }\end{array}$ \\
\hline $\begin{array}{l}\text { Individual job perfor- } \\
\text { mance }\end{array}$ & & & & & & \\
\hline Intention to use & 0.663 & & & & & 0.663 \\
\hline Knowledge sharing & 0.586 & 0.432 & & & & 0.586 \\
\hline Organizational support & 0.451 & 0.250 & 0.353 & & & 0.451 \\
\hline Perceived usefulness & 0.496 & 0.469 & 0.509 & 0.354 & & 0.496 \\
\hline Personal innovativeness & 0.449 & 0.580 & 0.329 & 0.297 & 0.497 & 0.449 \\
\hline
\end{tabular}

\subsection{Structural model}

To test the structural model used in this paper, the Structural Equation Modeling (SEM) modeling technique was used. This technique is a multivariate method that combines factor analysis and multiple regression, and thus simultaneously checks the interrelationships between manifest variables and latent constructs, but also between multiple latent constructs. Its main feature is the possibility of simultaneous assessment of several interdependent relationships [57]. The structural model is assessed based on R2 and Q2 and significance of paths. The value for the R2 should be equal or ver 0.1 [60]. The results in Table 5 presents that all values of R2 are above the 0.1 and confirms that predictive capability is established. Also, the values of Q2 are above zero that additionally confirms that there is significance in prediction of constructs. Furthermore, using SRMR, model fit was assessed. According to [57], values of SRMR needs to be below 0.1 and SRMR values for our model is 0.056 . 


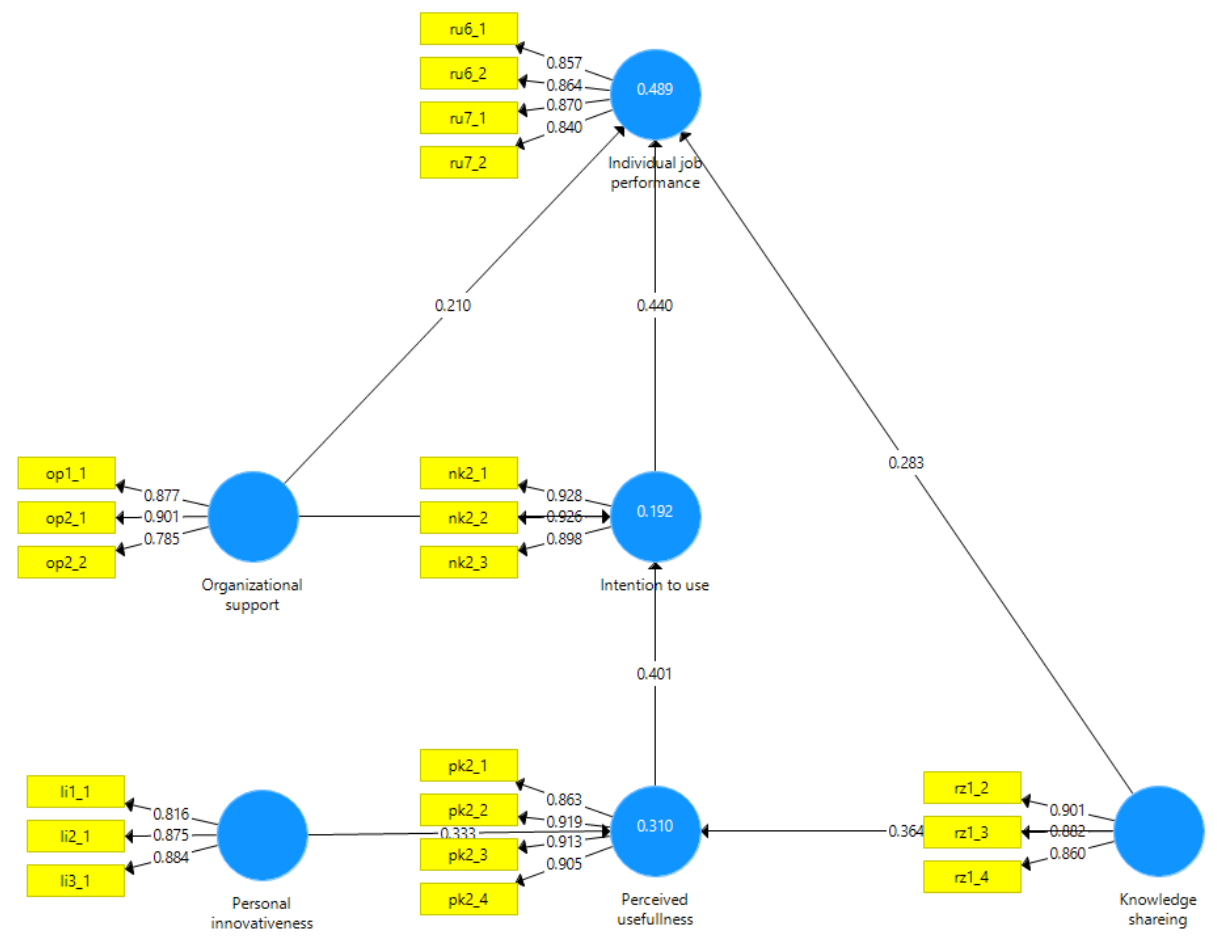

Fig. 2. Results of structural equation modeling analysis

In this part of the paper, an analysis of the relationships presented by the hypotheses is performed. Table 6 presents a standardized coefficient that shows the change in the dependent variable relative to the change in the standard deviation of the independent variable; a t-value that indicates whether a particular parameter is significantly different from zero in a population.

Table 6. Hypotheses testing

\begin{tabular}{|l|c|c|c|c|c|}
\hline & Hypothesis & $\boldsymbol{\beta}$ & STDEV & T Statistics & P Values \\
\hline H1 & Organizational support -> Intention to use & 0.093 & 0.058 & 1.609 & 0.108 \\
\hline H2 & Organizational support -> Individual job performance & 0.250 & 0.052 & 4.775 & 0.000 \\
\hline H3 & Intention to use -> Individual job performance & 0.440 & 0.062 & 7.113 & 0.000 \\
\hline H4 & Personal innovativeness -> Perceived usefullness & 0.333 & 0.070 & 4.727 & 0.000 \\
\hline H5 & Knowledge shareing -> Individual job performance & 0.347 & 0.069 & 5.029 & 0.000 \\
\hline H6 & Knowledge shareing -> Perceived usefullness & 0.364 & 0.076 & 4.758 & 0.000 \\
\hline H7 & Perceived usefullness -> Intention to use & 0.401 & 0.060 & 6.690 & 0.000 \\
\hline & & $\mathbf{R}^{2}$ & $\mathbf{Q}^{2}$ & & \\
\hline & Individual job performance & 0.489 & 0.347 & & \\
\hline & Intention to use & 0.192 & 0.155 & & \\
\hline & Perceived usefulness & 0.310 & 0.239 & & \\
\hline
\end{tabular}


Analysis of these data leads to the conclusion that organizational support has a positive but not significant impact on the intention to use $(\beta=0.093, \mathrm{t}=1.609, \mathrm{p}=$ $0.108)$. Personal innovativeness has a positive significant impact on perceived usefulness $(\beta=0.333, t=4.727, p=0.000)$. Knowledge sharing also has a positive impact on perceived usefulness $(\beta=0.364, \mathrm{t}=4.758, \mathrm{p}=0.000)$. Perceived usefulness has a positive impact on intention to use $(\beta=0.401, \mathrm{t}=6.690, \mathrm{p}=0.000)$. Intention to use have positive impact on individual job performances $(\beta=0.440, \mathrm{t}=7.113, \mathrm{p}=0.000)$. Organizational support has a positive significant impact on an individual's job performance $(\beta=0.250, t=4.775, p=0.000)$. Coefficient of determination for dependent variables is 0.489 for Individual job performance, 0.192 for Intention to use and 0.310 for Perceived usefulness respectively.

\section{$5 \quad$ Discussion and conclusion}

The results showed a positive but insignificant effect $(\beta=0.117, \mathrm{t}=1.748, \mathrm{p}=$ 0.080). of organizational support on intention to use e-learning systems. Although previous research confirms positive and significant impact within these variables, reasons for the difference in this research can be multiple. Companies in developing country that is subject of this research dealing in specific area when it comes to organizational policies and the way the organization is run. Consequently, the question is to what extent organizations in this area generally recognize the importance of organizational support. In addition, the concept of e-learning is relatively new in this area, so there is a possibility that some organizations have not yet identified the potential benefits of e-learning, and do not provide support in the form of incentives and accessibility and technical support. It is possible that people who running organizations are still more oriented towards the traditional form of learning at work, and these skills are acquired through training and education organized by the company, instead of learning through e-learning systems. The availability of technical support can also be one of the problems due to which the organization does not provide support to elearning. Another fact to consider is that half of the respondents are employed in state-owned firms, which are very likely to put less focus on an individual's personal progress and firm competitiveness than privately owned companies do. The fact that this hypothesis is not supported does not diminish the correctness of its formulation, but emphasizes the need for further research and examination of factors influencing this relationship, since the importance of organizational support for the intention to use e-learning system is mentioned and proven in many scientific papers [61]-[63]. Employer support with approval and resources, and a positive learning climate provides for training and development that depends on employee motivation to train. This may explain why previous results of employer support were inconsistent. Perhaps those with higher rather than lower motivation to learn and motivation through expectations, make more use of the support offered by their employers, to participate in training and development, and thus meet their important learning outcomes and needs [64]. Personal innovativeness of users has a positive impact on the perceived usefulness of e-learning systems is supported. It is natural that those respondents who 
are innovative and prone to "try out" new technologies are more likely to give the elearning system a chance, than those who are not. Therefore, such users will sooner discover all the potential advantages of the system, and perceive it as useful. In addition, users who are not innovative by nature are likely to ignore the potential benefits of e-learning, and will not perceive the system as useful, due to the fact that they are not prone to new technologies. This result of the analysis is actually a very significant item if we consider that the analysis also showed a negligible impact of organizational support on usage intent and perceived utility. If there is no support from the organization (or it is not significant).

\subsection{Theoretical and practical implications}

The subject of the analysis of this paper is e-learning in organizations and the influence of organizational support on the intention to use e-learning systems. In addition, internal factors related to the intention to use the e-learning system were analyzed, such as perceived usefulness, personal innovativeness, knowledge sharing and work performance. The analysis was conducted by applying the structural equation modeling method. The literature review analyzed the concepts and elements of elearning in organizations and the impact of organizational support on the intention to use e-learning systems. The same concepts were examined in both theoretical and empirical literature. The validity of the measurement models was verified. All relevant terms and methods used in the analysis are defined in detail. A model was constructed in accordance with observations and conclusions from previous scientific work and findings. What the work contributes to knowledge are the empirical results of the review of the used integrated structural model. Considering the fact that the respondents are employed in companies of different industries and in different positions, the research principle can be applied in different industries and can also serve as an idea for a new direction and way of conducting comparative analysis for existing theoretical assumptions. The findings also suggest that future research should focus on the factor of organizational support in the use of e-learning systems and how to maximize the influence of organizational support on the intention to use e-learning.

\subsection{Managerial contribution}

Day by day many changes are taking place in the world, people are living faster and the influence and use of technology is increasing. Aware of the times we live in, organizations must constantly keep up with and implement technology and technological changes to achieve the best possible results and maintain or increase competitiveness. Being a successful manager today is much more challenging than it used to be. Faced with constant change, managers are often forced to make decisions and assessments "on the fly." Every successful manager today certainly recognizes the benefits and importance of technology, and therefore e-learning, when it comes to learning. Consequently, e-learning systems are popping up more and more in organizations. Since the concept of e-learning is relatively new in developing countries and definitely not as developed as it should be, this paper can be of great importance to managers 
in implementing and using e-learning systems in business. The main finding of the analysis is that organizational support has no significant influence on the intention to use the e-learning system. This point can be of great importance for managers who may not have realized the benefits of e-learning themselves or may not provide adequate support for their employees to use e-learning. Judging from the analysis of the research, managers should definitely reconsider their way of working and their attitude towards employees when it comes to using e-learning systems. In addition, other findings indicating that perceived usefulness influences intention to use, that personal innovativeness and knowledge sharing influence perceived usefulness, and that organizational support influences individuals' work performance may be very important findings for managers and provide them with some guidance for future ways of working, implementing e-learning systems and attitudes towards employees.

\subsection{Limitations and future research}

In addition to presenting the results of this scientific research, it is necessary to consider some limitations. First, the model was validated on only one sample in a developing country in one point in time and should be validated on another sample so that the results can be generalized and the model can be used worldwide. Second, the model used cross-sectional data collected only at one point in time, whereas the model could be better generalized if longitudinal data were used. In addition, there are other factors that may influence the use of e-learning systems that need to be considered in future research. Despite the limitations mentioned above, we believe that the model created in this paper, together with the data obtained through the analysis, is very important for organizations that are increasingly involved in e-learning and also for future academic work that will address this topic.

\section{References}

[1] Y. Tyurina et al., "E-Learning for SMEs," Int. J. Emerg. Technol. Learn., vol. 16, no. 2, pp. 108-119, 2021.

[2] A. Kapo, A. Mujkic, L. Turulja, and J. Kova, "Continuous e-learning at the workplace : the passport for the future of knowledge," 2020, doi: 10.1108/ITP-04-2020-0223.

[3] J. F. J. Zhang, Dongsong; Zhao, J. Leon; Zhou, Lina; Nunamaker, "Can e-learning replace classrom learning?," Commun. ACM, vol. 47, no. 5, pp. 74-79, 2004.

[4] R. C. Clark and R. E. Mayer, "e-Learning and the Science of Instruction: Proven Guidelines for Consumers and Designers of Multimedia Learning: Third Edition," $e$ Learning Sci. Instr. Proven Guidel. Consum. Des. Multimed. Learn. Third Ed., vol. 42, no. 5, pp. 41-43, 2012. https://doi.org/10.1002/9781118255971

[5] N. S. Chen, K. M. Lin, and Kinshuk, "Analysing users' satisfaction with e-learning using a negative critical incidents approach," Innov. Educ. Teach. Int., vol. 45, no. 2, pp. 115-126, 2008. https://doi.org/10.1080/14703290801950286

[6] J.-W. Lee, "Online support service quality, online learning acceptance, and student satisfaction," Internet High. Educ., vol. 13, no. 4, pp. 277-283, Dec. 2010. https:// doi.org/10.1016/j.iheduc.2010.08.002 
[7] L. Rhoades and R. Eisenberger, "Perceived organizational support: A review of the literature," J. Appl. Psychol., vol. 87, no. 4, pp. 698-714, 2002.

[8] M. G. Aboelmaged, "Knowledge sharing through enterprise social network (ESN) systems: motivational drivers and their impact on employees' productivity," J. Knowl. Manag., vol. 22, no. 2, pp. 362-383, 2018. https://doi.org/10.1108/JKM-05-2017-0188

[9] A. Y. L. Chong, F. T. S. Chan, M. Goh, and M. K. Tiwari, "Do interorganisational relationships and knowledge-management practices enhance collaborative commerce adoption?," Int. J. Prod. Res., vol. 51, no. 7, pp. 2006-2018, 2013, https://doi.org/10.1080 /00207543.2012.701776

[10] S. Iglesias-Pradas, Á. Hernández-García, and P. Fernández-Cardador, "Social factors' influences on corporate wiki acceptance and use," J. Bus. Res., vol. 68, no. 7, pp. 14811487, 2015. https://doi.org/10.1016/j.jbusres.2015.01.038

[11] S. A. Salloum, M. Al-Emran, K. Shaalan, and A. Tarhini, "Factors affecting the E-learning acceptance: A case study from UAE," Educ. Inf. Technol., vol. 24, no. 1, pp. 509-530, 2019. https://doi.org/10.1007/s10639-018-9786-3

[12] N. Dixon, "The neglected receiver OF KNOWLEDGE SHARING," Ivey Bus. J., vol. 66, no. 4, pp. 35-40, 2002.

[13] E. Salas, S. I. Tannenbaum, K. Kraiger, and K. A. Smith-Jentsch, "The Science of Training and Development in Organizations: What Matters in Practice," Psychol. Sci. Public Interes. Suppl., vol. 13, no. 2, pp. 74-101, 2012. https://doi.org/10.1177\% 2F1529100612436661

[14] A. M. Tsai, S. Journal, and M. Tsai, "International Forum of Educational Technology \& Society The Model of Strategic e-Learning: Understanding and Evaluating Student eLearning from Metacognitive Perspectives Published by: International Forum of Educational Technology \& Society The Model of," J. Educ. Technol. Soc., vol. 12, no. 1, pp. 34-48, 2009.

[15] E. T. Welsh, C. R. Wanberg, K. G. Brown, and M. J. Simmering, "E-learning: emerging uses, empirical results and future directions," Int. J. Train. Dev., vol. 7, no. 4, pp. 245-258, 2003. https://doi.org/10.1046/j.1360-3736.2003.00184.x

[16] D. A. Hofmann and A. Stetzer, "A cross-level investigation of factors influencing unsafe behaviors and accidents," Pers. Psychol., vol. 49, no. 2, pp. 307-339, 1996. https:// doi.org/10.1111/j.1744-6570.1996.tb01802.x

[17] J. Naujokaitiene, M. Tereseviciene, and V. Zydziunaite, "Organizational support for employee engagement in technology-enhanced learning," SAGE Open, vol. 5, no. 4, pp. 19, 2015. https://doi.org/10.1177\%2F2158244015607585

[18] B. Cheng, M. Wang, J. Moormann, B. A. Olaniran, and N. S. Chen, "The effects of organizational learning environment factors on e-learning acceptance," Comput. Educ., vol. 58, no. 3, pp. 885-899, 2012. https://doi.org/10.1016/j.compedu.2011.10.014

[19] R. Eisenberger, P. Fasolo, and V. Davis-LaMastro, "Perceived organizational support and employee diligence, commitment, and innovation.," J. Appl. Psychol., vol. 75, no. 1, pp. 51-59, 1990. https://doi.org/10.1037/0021-9010.75.1.51

[20] S. J. Wayne, L. M. Shore, and R. C. Liden, "Perceived organizational support and leadermember exchange: A social exchange perspective," Acad. Manag. J., vol. 40, no. 1, pp. 82-111, 1997. https://doi.org/10.5465/257021

[21] S. J. Wayne, L. M. Shore, W. H. Bommer, and L. E. Tetrick, "The role of fair treatment and rewards in perceptions of organizational support and leader-member exchange," $J$. Appl. Psychol., vol. 87, no. 3, pp. 590-598, 2002. https://doi.org/10.1037/0021$\underline{9010.87 .3 .590}$ 
[22] S. Armeli, R. Eisenberger, P. Fasolo, and P. Lynch, "Perceived organizational support and police performance: The moderating influence of socioemotional needs," J. Appl. Psychol., vol. 83, no. 2, pp. 288-297, 1998. https://doi.org/10.1037/0021-9010.83.2.288

[23] R. Eisenberger, R. Huntington, S. Hutchison, and D. Sowa, "Perceived organizational support," J. Appl. Psychol., vol. 71, no. 3, pp. 500-507, 1986. https://doi.org/10.1037/0021 $\underline{-9010.71 .3 .500}$

[24] W. A. Hochwarter, L. A. Witt, D. C. Treadway, and G. R. Ferris, "The interaction of social skill and organizational support on job performance," J. Appl. Psychol., vol. 91, no. 2, pp. 482-489, 2006. https://doi.org/10.1037/0021-9010.91.2.482

[25] M. L. Kraimer, S. J. Wayne, and R. A. Jaworski, "Sources of support and expatriate performance: The mediating role of expatriate adjustment," Pers. Psychol., vol. 54, no. 1, pp. 71-99, 2001. https://doi.org/10.1111/j.1744-6570.2001.tb00086.x

[26] S. Mohammadyari and H. Singh, "Computers \& Education Understanding the effect of elearning on individual performance : The role of digital literacy," vol. 82, 2015.

[27] J. B. Arbaugh, "Managing the on-line classroom. A study of technological and behavioral characteristics of web-based MBA courses," J. High Technol. Manag. Res., vol. 13, no. 2, pp. 203-223, 2002. https://doi.org/10.1016/S1047-8310(02)00049-4

[28] S. Y. McGorry, "Measuring quality in online programs.," Internet High. Educ., vol. 6, no. 2, pp. 159-177, 2003.

[29] E. M. Rogers, "Diffusion of preventive innovations. Addictive Behaviour," Addict. Behav., vol. 27, pp. 989-993, 2002. https://doi.org/10.1016/S0306-4603(02)00300-3

[30] R. Agarwal and J. Prasad, "A Conceptual and Operational Definition of Personal Innovativeness in the Domain of Information Technology," Inf. Syst. Res., vol. 9, no. 2, pp. 204-215, 1998. https://doi.org/10.1287/isre.9.2.204

[31] J. Lu, C. S. Yu, C. Liu, and J. E. Yao, "Technology acceptance model for wireless Internet," Internet Res., vol. 13, no. 3, pp. 206-222, 2003. https://doi.org/10.1108/ 10662240310478222

[32] J. N. Cummings, "Work Groups, Structural Diversity, and Knowledge Sharing in a Global Organization," Manage. Sci., vol. 50, no. 3, pp. 352-364, 2004. https://doi.org/10.1287/ mnsc. 1030.0134

[33] S. Assegaff, A. R. C. Hussin, and H. M. Dahlan, "Perceived benefit of knowledge sharing: Adapting TAM model," 2011 Int. Conf. Res. Innov. Inf. Syst. ICRIIS'11, pp. 1-6, 2011. https://doi.org/10.1109/icriis.2011.6125744

[34] G. W. Bock and Y. G. Kim, "Breaking the Myths of Rewards: An Exploratory Study of Attitudes about Knowledge Sharing," Inf. Resour. Manag. J., vol. 15, no. 2, pp. 14-21, 2002. https://doi.org/10.4018/irmj.2002040102

[35] A. H. . Yuen and W. W. K. Ma, "Knowledge sharing and teacher acceptance of web based learning system," Proc. 21st ASCILITE Conf., pp. 975-983, 2004.

[36] R. Cheung and D. Vogel, "Predicting user acceptance of collaborative technologies: An extension of the technology acceptance model for e-learning," Comput. Educ., vol. 63, pp. 160-175, 2013. https://doi.org/10.1016/j.compedu.2012.12.003

[37] S. Kim, "Factors affecting the use of social software: TAM perspectives," Electron. Libr., vol. 30, no. 5, pp. 690-706, 2012. https://doi.org/10.1108/02640471211275729

[38] M. Al-Emran and T. Teo, "Do knowledge acquisition and knowledge sharing really affect e-learning adoption? An empirical study," Educ. Inf. Technol., 2019. https://doi.org/ 10.1007/s10639-019-10062-w

[39] F. Davis, "Perceived usefulness, perceived ease of use, and user acceptance of information technology.," MIS Q., vol. 13, no. 3, pp. 319-340, 1989. https://doi.org/10.2307/249008 
[40] V. Venkatesh, M. G. Morris, G. B. Davis, and F. D. Davis, "User acceptance of information technology: Toward a unified view," MIS Q., vol. 27, no. 3, pp. 425-478, 2003. https://doi.org/10.2307/30036540

[41] S. Ruangvanich and P. Piriyasurawong, "Structural equation model of acceptance cloud learning for sustainability usage in higher education institutes," Int. J. Emerg. Technol. Learn., vol. 14, no. 10, pp. 18-33, 2019. https://doi.org/10.3991/ijet.v14i10.10045

[42] A. Bhattacherjee, "Understanding Information Systems Continuance: An ExpectationConfirmation Model," Manag. Inf. Syst., vol. 25, no. 3, pp. 351-370, 2001. https:// doi.org/10.2307/3250921

[43] M. M. Abbad, D. Morris, A. Al-Ayyoub, and J. M. Abbad, "Students' decisions to use an elearning system: A structural equation modelling analysis," Int. J. Emerg. Technol. Learn., vol. 4, no. 4, pp. 4-13, 2009. https://doi.org/10.3991/ijet.v4i4.928

[44] P. B. Seddon and M. . Kiew, "A partial test and development of DeLone and McLean's model of IS success," Australas. J. Inf. Syst., vol. 4, no. 1, pp. 90-109, 1996. https://doi.org/10.3127/ajis.v4i1.379

[45] K. A. Saeed and S. Abdinnour-Helm, "Examining the effects of information system characteristics and perceived usefulness on post adoption usage of information systems," Inf. Manag., vol. 45, no. 6, pp. 376-386, 2008. https://doi.org/10.1016/j.im.2008.06.002

[46] B. H. Erickson, "Some problems of interference from chain data," Sociol. Methodol., vol. 10, pp. 276-302, 1979.

[47] S. Sudman and G. Kalton, "New developments in the sampling of special populations," Annu. Rev. Sociol., vol. 12, pp. 401-429, 1986. https://doi.org/10.1146/annurev.so. 12.080186 .002153

[48] J. B. Tracey and M. J. Tews, "Construct validity of a general training climate scale," Organ. Res. Methods, vol. 8, no. 4, pp. 353-374, 2005. https://doi.org/10.1177\% 2F1094428105280055

[49] Y. M. Cheng, "Antecedents and consequences of e-learning acceptance," Inf. Syst. J., vol. 21, no. 3, pp. 269-299, 2011. https://doi.org/10.1111/j.1365-2575.2010.00356.x

[50] Venkatesh; Viaswanath and Davis; Fred D., "A Theoretical Extension of the Technology Acceptance Model: Four Longitudinal Field Studies," Manage. Sci., vol. 46, no. 2, pp. 186-204, 2000. https://doi.org/10.1287/mnsc.46.2.186.11926

[51] C. M. Chiu, S. Y. Sun, P. C. Sun, and T. L. Ju, "An empirical analysis of the antecedents of web-based learning continuance," Comput. Educ., vol. 49, no. 4, pp. 1224-1245, 2007. https://doi.org/10.1016/j.compedu.2006.01.010

[52] Z. Belkhamza and M. M. Bin Abdullah, "Trainee characteristics and organizational environment for enhancing individual performance in e-learning involvement," Int. J. Web-Based Learn. Teach. Technol., vol. 14, no. 2, pp. 88-101, 2019. https://doi.org/10. 4018/ijwltt.2019040106

[53] J. . Tracey and M. J. Tews, "Construct Validity of a General Training Climate Scale," Organ. Res. Methods, vol. 8, no. 4, pp. 353-374, 2005. https://doi.org/10.1177\%2F 1094428105280055

[54] J. C. Anderson and D. W. Gerbing, "Structural equation modeling in practice: A review and recommended two-step approach," Psychol. Bull., vol. 103, no. 3, pp. 411-423, 1988. https://doi.apa.org/doi/10.1037/0033-2909.103.3.411

[55] Bollen, K. A. and J. S. Long, Testing structural equation models. Newbury Park, CA: Sage, 2003.

[56] G. D. Garson, Structural equation modeling. Asheboro, NC: Statistical Publishing Associates, 2015. 
[57] R. E. Hair, J.F., Black, W.C., Babin, B.J., Anderson, Multivariate Data Analysis (7th Edition). Prentice Hall; 7 edition, 2010.

[58] C. Fornell and Da. F. Larcker, "Evaluating Structural Equation Models with Unobservable Variables and Measurement Error," J. Mark. Res., vol. 18, no. 1, pp. 39-50, 1981. https://doi.org/10.1177/002224378101800104

[59] J. Henseler, C. M. Ringle, and M. Sarstedt, "A new criterion for assessing discriminant validity in variance-based structural equation modeling," J. Acad. Mark. Sci., vol. 43, no. 1, pp. 115-135, 2015. https://doi.org/10.1007/s11747-014-0403-8

[60] R. F. Falk and N. B. Miller, "A Primer for Soft Modeling," Univ. Akron Press, no. April, p. 80,1992 .

[61] A. Keramati, M. Afshari-Mofrad, and A. Kamrani, "The role of readiness factors in Elearning outcomes: An empirical study," Comput. Educ., vol. 57, no. 3, pp. 1919-1929, 2011. https://doi.org/10.1016/j.compedu.2011.04.005

[62] Y. H. Chuo, C. H. Tsai, and Y. L. Lan, "The Effect of Organizational Support and Self Efficacy on the Usage Intention of E-Learning System in Hospital," Key Eng. Mater., vol. 467-469, no. 14, pp. 2137-2142, 2011. https://doi.org/10.4028/www.scientific.net/KEM. 467-469.2137

[63] J. Aselage and R. Eisenberger, "Perceived organizational support and psychological contracts: A theoretical integration," J. Organ. Behav., vol. 24, no. SPEC. ISS., pp. 491509, 2003. https://doi.org/10.1002/job.211

[64] P. Tharenou, "The relationship of training motivation to participation in training and devel-opment," J. Occup. Organ. Psychol., vol. 74, no. 3, pp. 599-621, 2001. https://doi. org/10.1348/096317901167541

\section{Authors}

Belma Cevra has completed a master's thesis in Management and Information Systems in a program run by the School of Economics and Business in collaboration with Microsoft. Belma is a hardworking and dedicated student. She is active in academic and professional activities, with a focus on information technology.

Amra Kapo is employed as an associate professor at the Department of Information Technology Management, Faculty of Economics, University of Sarajevo. She is engaged as a researcher on various projects funded by state institutions or by the European Commission (for example, projects from IPA funds). In addition to the above, for the last ten years he has been engaged in online education, both at the home institution and in various projects for the development of strategies, methodologies and online courses in the public and private sector in Bosnia and Herzegovina. She is the (co) author of several scientific papers and chapters in the book, and she has presented her research at several scientific conferences.

Tarik Zaimović is an associate professor at the School of Economics and Business University of Sarajevo. Prof. Zaimović published a number of research studies and publications, (co)authored eight books and some of the major Government strategic documents. Since April 2019, professor Zaimović is serving as a Vice-rector for financial affairs at the University of Sarajevo. With over 22 years of experience in design and delivery of different types of education programs, from undergraduate, postgraduate, MBA and tailored educational programs, prof. Zaimović has extensive 
experience in advanced teaching methodologies and technics, as well as different tools for on- and off-site learning, Internet-based training, interactive multimedia content, distance learning and interactive instructional and content design.

Lejla Turulja is an associate professor at the Department of Management and Information Technology at the Faculty of Economics, University of Sarajevo. She is the Director of the Financial Management and Marketing Management programs at the School of Economics in Sarajevo, the only EPAS accredited programs in $\mathrm{BiH}$, and is in charge of accreditation processes at the home faculty. As a U.S. State Department Fellow, she has been a guest at Northwestern University in Chicago, USA; and as part of the Erasmus exchange she lectured at the Vienna University of Economics and Business and the Wroclaw University of Economics. She has also been engaged as a researcher on various national and international projects (for example, projects from IPA funds). She is the (co) author of several scientific papers published in indexed journals and conferences, several books and book chapters.

Article submitted 2021-09-17. Resubmitted 2021-10-21. Final acceptance 2021-10-22. Final version published as submitted by the authors. 